\title{
Pengembangan Kewirausahaan Berbasis Industri Kreatif Bagi Jamaah Wanita Majelis Taklim Di Desa Kepek
}

\author{
Umi Musaropah $^{1}$, Suharto ${ }^{2}$, Daluti Delimanugari ${ }^{3}$, Agus Suprianto ${ }^{4}$, Rubini $^{5}$, \\ Retno Kurnianingsih ${ }^{6 *}$, Citra Ayudiati ${ }^{7}$ \\ ${ }^{1,2,3,4}$ STAI Yogyakarta, ${ }^{5}$ STAI Masjid Syuhada, ${ }^{6,7}$ Universitas Cokroaminoto Yogyakarta \\ *Penulis Koresponden, email: retnokurnianing84@gmail.com
}

\begin{abstract}
Abstrak
Pengembangan kewirausahaan berbasis industri kreatif bagi wanita jamaah majelis taklim (MT) di desa Kepek dilaksanakan dengan metode PAR (Participation Action Research) yang bertujuan mendorong pikiran kreatifitas bertekanan pada pertanyaan dan bimbingan yang berorientasi pada peserta. Pengembangan kewirausahaan bagi jamaah wanita MT di desa Kepek Gunung Kidul, bisa tercapai secara baik. Diantaranya adalah; Perlu ada tindak lanjut dalam rangkaian pendampingan serta peningkatan keterampilan, baik yang bersifat utama maupun pendukung usaha. Potensi kearifan lokal yang baik bisa dikonversi dalam bentuk nilai ekonomi. Pengembangan jaringan pemasaran secara massif perlu dipertimbangkan untuk memberikan dampak ekonomi lebih besar bagi masyarakat sekitar. Pemerintah disarankan untuk mendukung penggalian lebih dalam kearifan ekonomi lokal masyarakat Gunung Kidul dalam pengembangan pendidikan kewirausahaan sehingga mampu memberikan dampak positif secara langsung bagi warganya.
\end{abstract}

Kata kunci: industry kreatif, majelis taklim, kewirausahaan, pengembangan

\begin{abstract}
Entrepreneurship development based on creative industries for women congregation majelis taklim (MT) in Kepek village is carried out using the PAR (Participation Action Research) method which aims to encourage creative minds by pressing questions and participant-oriented guidance. Entrepreneurship development for MT female congregation in Kepek Gunung Kidul village can be achieved well. Among others are; There needs to be a follow-up in a series of mentoring and skills improvement, both for the main and supporting the business. The potential for good local wisdom can be converted into economic values. Massive development of marketing networks needs to be considered in order to have a bigger economic impact on the surrounding community. The government is advised to support deeper exploration of the local economic wisdom of the people of Gunung Kidul so that it can have a direct positive impact on its residents.

Keywords: creative industries, majelis taklim, Entrepreneurship, development
\end{abstract}




Umi Musaropah, Suharto, Daluti Delimanugari, Agus Suprianto, Rubini,

Retno Kurnianingsih, Citra Ayudiati

\section{Pendahuluan}

Sektor usaha informal, mikro, kecil, dan menengah Indonesia sedang mengalami stagnasi karena kesulitan mendapat akses permodalan, akses manajerial, akses pemasaran dan lain-lain. Fasilitas akses permodalan dari pemerintah hanya dinikmati oleh pelaku usaha yang bankable, yang jumlahnya kurang dari 1\% dari jumlah penduduk NKRI (Asmoro 2009).

Perluasan jaringan modal, produksi, maupun distribusi menjadi alternative yang patut diperhatikan secara sungguh. Segala bentuk kerja sama, jaringan dalam sosial ekonomi kemasyarakatan patut dilirik untuk diseleksi secara hati-hati guna mendukung peningkatan pergerakan ekonomi (Huda 2016). Daulay (2014) telah menawarkan jaringan usaha yang melibatkan ibuibu jamaah majelis taklim MT seperti yang telah terjadi di Kota Medan.

Bagi Win (2012) MT di Indonesia memiliki arti yang beragam. kelompok pengajian agama Islam atau pembacaannya, juga dikenal dengan forum pembelajaran agama, temu dakwah, pertemuan masyarakat untuk kajian Islam atau Alquran, tapi juga bisa menunjukkan pertemuan pribadi untuk ajaran agama, termasuk kelompok diskusi agama ala salon. Tetapi Marcus dalam Winn (2012) telah membatasi untuk kegiatan agama bagi kelamin tertentu. Pertemuan keagamaan khusus perempuan seperti pengajian atau kelompok muslimah tradisional. Hubungan yang erat dalam dakwah dan pendidikan Islam bagi perempuan dalam MT telah memunculkan banyak ulama-ulama perempuan di Indonesia (Burhanuddin 2002). Selain pendidikan khusus, MT juga diakui memberi perang penting dalam baca al-Quran secara fasih bagi usia dewasa (Rahayu et al. 2019). Mereka juga bisa mendalami implementasi nilai-nilai kemasyarakatan yang umum dalam pesantren (Nadjib H. et al. 2019)

Keberadaan majelis taklim (MT) sangat penting dalam meningkatkan kualitas iman dan ke-Islaman umat bahkan respon mereka terhadap segala persoalan kemasyarakatan dalam konsistensi ketakwaan kepada Allah SWT (Nadjih dan Santoso 2015). Sagala (2019) menyebutnya, "Lembaga pendidikan alternatif yang bersifat non-formal dan diminati oleh kaum 
perempuan sebagai peserta tetap dalam pengajian di bidang pendidikan islam dan gerakan sosial keagamaan"

Meski demikian selama berjalan, kelembagaan pendidikan agama nonformal itu tidak terpaku pada pakem terntentu. Huda (1986) sangat longgar terhadap perangkat dan aturan kependidikannya termasuk lama waktu belajar.

"Sebagai institusi pendidikan Islam yang berbasis masyarakat, peran strategis MT terutama terletak dalam mewujudkan learning society, yaitu suatu masyarakat yang memiliki tradisi belajar tanpa dibatasi oleh usia, jenis kelamin, tingkat pendidikan, juga dapat menjadi wahana belajar, serta menyampaikan pesan-pesan keagamaan, wadah pengembangan silaturahmi dan berbagai kegiatan keagamaan lainnya bagi semua lapisan masyarakat" Hirzin dalam Santoso, Nadjih, dan Samroni (2015).

Namun daya guna bagi pengembangan masyarakat tidak terbatas pada pendidikan agama. Jamaah MT yang sebagian besar terdiri dari para wanita dan ibu telah bisa berpartisipasi dalam berbagai sector pembangunan di lingkungannya melalui MT. Kehidupan mereka mengikuti dinamika pesantren yang peka terhadap pengembangan ekonomi (Fauroni dan Quraisy 2019). Variasi pengetahuan yang diperoleh di MT mendukung optimalisasi mereka di keluarga dan masyarakat (Helmawati 2018). Jamaah pun mendapatkan pengetahuan hokum tentang pernikahan usia dini (Zainuri et al. 2019), atau fenomena sosial lainnya yang relevan.

Di bidang peningkatan ekonomi industri berbasis rumah tangga (home industry), MT telah banyak berperan bahkan menjadi inisiator kesejahteraan di lingkungannya. Untuk menggalakkan semangat kewirausahaan di kalangan wanita jamaah MT perkotaan di Kelurahan Berua, Rosmawati, Ishak, dan Nurhilaliah (2017) telah mengadakan pelatihan motivasi dan wirausaha. Bisri dan Setiawan (2019) telah mengadakan program pelatihan kewirausahaan Syariah bagi MT di Desa Balokang Kota Banjar untuk meluaskan wawasan dan pengetahuan ibu-ibu jamaah tentang muamalah yang sesuai syariah. Di bagian lain, Ibu-ibu anggota MT Masjid Al-Ikhlas di Kecamatan Koto Tangan telah pelatihan keterampilan merajut untuk 
Umi Musaropah, Suharto, Daluti Delimanugari, Agus Suprianto, Rubini,

Retno Kurnianingsih, Citra Ayudiati

produksi barang bernilai ekonomis (Rosha et al. 2019). Susiana, Widyastuti, dan Sari (2017) juga memberdayakan MT dalam produk yang sama disertai pelatihan dasar-dasar manajemen di pedesaan Deli Serdang. Sutrisno (2018) bersama Oemah Kedelai telah mengajak ibu-ibu jamaah MT di RW 62 di salah satu perumahan perkotaan Kabupaten Sleman dalam pelatihan produksi kedelai menjadi susu kedelai dan nugget. (Hindarti, Sudjoni, dan Khoiriyah 2018) telah mendampingi kelompok MT di Kecamatan Patihrowo dalam pengolahan bawang merah goreng. Semuanya kegiatan ibu MT itu memiliki tujuan pemberian ketrampilan usaha sekaligus pembentukan jaringan ekonomi produksi sehingga pendapatan keluarga jamaah bisa meningkat.

Kaum ibu dari MT di desa Kepek Wonosari Gunung Kidul merupakan salah satu suatu komunitas yang terabaikan dari program pembangunan. Meskipun dalam lima belas tahun terakhir, yang bermula kelompok pengajian ibu-ibu yang sebagian besar berprofesi sebagai penjual jamu berinisiatif mengembangkan home industri pembuatan jamu serbuk instan berbasis herbal. Inisiatif ini didukung oleh salah satu tokoh masyarakat setempat, sehingga terbentuklah beberapa kelompok usaha jamu serbuk instan berbasis herbal.

Pilihan usaha kreatif berbasis home industry ini tepat sehubungan dengan lingkungan pedesaan yang pada umumnya merupakan lahan pertanian. Selain itu sekelompok masyarakat yang berprofesi sebagai pembuat telur asin dan pelaku usaha konfeksi. Sayangnya para pelaku usaha ekonomi rumahan ini tidak mengalami perkembangan yang signifikan karena adanya berbagai kelemahan dalam manajemen dan pemasarannya. Adanya ketersediaan para pelaku usaha rumahan merupakan potensi ekonomi strategis yang mendukung terhadap pemberdayaan ekonomi masyarakat Kepek.

Terdapat beberapa alasan lain mengapa MT wilayah pedesaan itu menjadi masyarakat binaan; 1) Masyarakat Kepek termasuk di dalamnya jamaah MT telah mempunyai potensi-potensi kewirausahaan, yaitu berbagai industri kreatif rumahan, 2) Akar budaya dalam kegiatan ekonomi bagi 
sebagian masyarakat Kepek telah ada secara turun-temurun. Dengan demikian akar budaya tersebut merupakan modal utama bagi perubahan sosial dan pencapaian keberdayaan ekonomi. 3) MT menempati posisi cukup sentral sebagai penggerak masyarakat dalam kewirausahaan di Kepek. 4) Terdapat semangat dan potensi simbiosis mutualisme antara budaya masyarakat setempat dengan ajaran Tarekat Sidiqiyah yang dianut oleh sebagian masyarakat Kepek. Semangat dan potensi ini praktis merupakan modal utama yang sangat bernilai bagi tercapainya suatu pendidikan kewirausahaan yang berorientasi transformasi sosial ekonomi industry kreatif.

\section{Metode}

Gambar 1

\section{Alur Pengabdian Kepada Masyarakat}

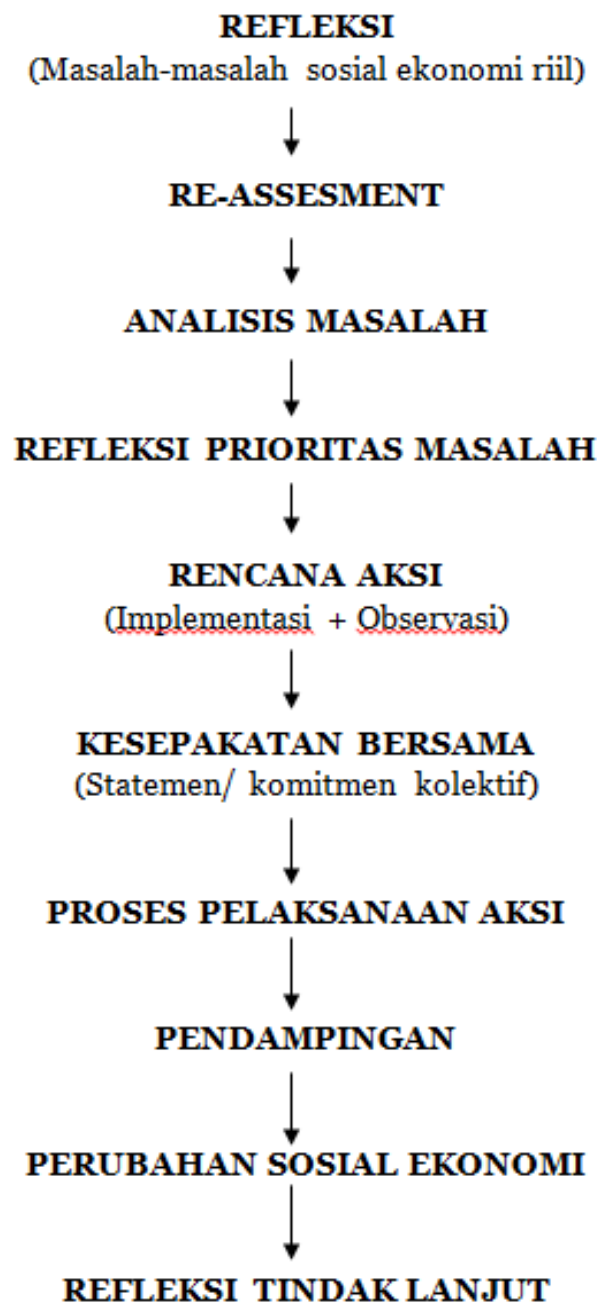


Umi Musaropah, Suharto, Daluti Delimanugari, Agus Suprianto, Rubini,

Retno Kurnianingsih, Citra Ayudiati

Pemberdayaan dan pengabdian kepada masyarakat dalam pengembangan pengetahuan dan sikap tentang industri kreatif ini mengikuti Jacobs (2016) yang mendorong pikiran kreatifitas dengan meramu pemacu dari metode PAR (Participation action Research) yang menekankan pertanyaan (Hermawan 2016) dan bimbingan yang berorientasi pada peserta/ siswa (Sarumaha 2016). Dalam pendidikan, seorang peneliti kelas mungkin segera memahami dalam konteks penelitian tindakan kelas yang menuntut keakftifan semua pihak dalam intervensi yang dilakukan dan menghendaki perbaikan berkelanjutan (Prihantoro dan Hidayat 2019) Secara umum, metode PAR terdiri dari eksplanasi dan tematis. PAR pertama digunakan saat analisa kebutuhan, permasalahan, termasuk pemecahannya sehingga tindakan perubahan bisa diputuskan. Sedangkan analisa PAR Tematik difokuskan pada evaluasi dan monitor kegiatan yang sudah berjalan, sebagai (Gaffney 2008). Pengunaan metoda komunikasi alternatif dalam PAR(Participation Action Research) dari Jacobs bekerja dalam proses sebagai berikut;

Dengan PAR setiap individu maupun kelompok jamaah diberdayakan dengan keterampilan yang dibutuhkan dalam memproduksi perubahan di lingkungan mereka (Fauroni, Ahmad, dan Kostradiharto 2016). Peningkatan keterampilan biasanya disertai dengan penciptaan kelompok sosial yang bekerja untuk motivasi kebersamaan.

Para pengabdi atau pengembang komunitas harus memahami cara bekerja bersama-sama dengan individu dan bagaimana memengaruhi kedudukan masyarakat dalam konteks institusi sosial yang lebih besar. Prinsip penting dalam pengembangan atau pemberdayaan (empowerment) masyarakat adalah adanya pelibatan atau pemberdayaan masyarakat dalam program yang dilaksanakan. Pelibatan masyarakat dimulai dari proses perencanaan, pengorganisasian, pelaksanaan, evaluasi, dan tindak lanjut. Pengembangan atau pemberdayaan masyarakat memiliki tiga karakteristik utama, yaitu berbasis komunitas (community based), berbasis sumber daya setempat (local resource based), dan berkelanjutan (sustainable). Pengembangan atau pemberdayaan masyarakat mengandalkan peran serta dan kekuatan masyarakat (Bisri dan Setiawan 2019).

\section{Pelaksanaan Pengembangan Kewirausahaan}


Sesuai paparan sebelumnya, pengembangan kewirausahaan batik di Kepek bagi jamaah MT dilakukan secara bertahap. Proses aksi pengabdian secara garis besar terbagi menjadi dua proses utama yaitu pelatihan manajemen keuangan bisnis rumahan, dan pelatihan pengembangan industri kreatif rumahan yang dilengkapi dengan kunjungan ke salah satu usaha kreatif .

Pelatihan Manajemen Keuangan Bisnis Rumahan

Pelatihan tahap satu ini menghadirkan dua orang narasumber yang memiliki kapasitas dalam bidang manajemen keuangan, serta bisnis. Tema mengenai "Dasar-dasar Pengembangan Bisnis Perspektif Bisnis Syari'ah", disampaikan oleh seorang narasumber yang telah lama mengkaji mengenai bisnis Islam. Sehingga diharapkan seluruh peserta yang hadir pada kesempatan hari itu, mesa mengelola bisnisnya sesuai dengan prinsip-prinsip yang ada dalam nash baik itu al-Qur'an maupun as-Sunnah. Tema kedua mengangkat tema mengenai "Manajemen Keuangan Bisnis Rumahan" yang disampaikan oleh akademisi yang memang merupakan spesifikasi bidang yang digelutinya. Tema ini diangkat dengan maksud, agar seluruh peserta yang hadir memiliki kemampuan mengelola keuangan yang lebih tertata dan professional, yang ditandai dengan pembedaan keuangan rumah tangga dengan keuangan usaha yang dijalankannya.

Pelatihan tahap satu ini, dihadiri oleh 28 orang, semuanya merupakan orang-orang yang telah memiliki usaha baik yang kecil maupun menengah. Selain itu, peserta yang hadir juga sebagian dipandang memiliki potensi yang kuat dalam membantu mensosialisasikan hasil pelatihan kepada masyarakat lainnya, yang tidak hadir dalam pelatihan. Dengan cara seperti ini, diharapkan pelatihan yang telah dilaksanakan guna meningkatkan kualitas ekonomi masyarakat sekitar, bisa terlaksana dengan baik sekaligus memberikan implikasi yang positif serta signifikan dalam meningkatkan tarap kehidupan masyarakat, khususnya komunitas tharekan di Wonosari.

Pelatihan Pengembangan Industri Kreatif Rumahan

Pelatihan tahap dua, dan merupakan pelatihan lanjutan yang telah disinergikan agar bisa menghasilkan masyarakat yang mandiri, kreatif, dan 
Umi Musaropah, Suharto, Daluti Delimanugari, Agus Suprianto, Rubini,

Retno Kurnianingsih, Citra Ayudiati

selalu meningkatkan taraf kehidupan perekonomian. Seperti yang telah diuraikan sebelumnya, bahwa penelitian ini merupakan penelitian lanjutan, yang dihadiri oleh $100 \%$, dari 28 orang yang hadir dalam pelatihan tahap satu. Pelatihan ini memang ditujukan untuk peserta yang telah menghadiri pelatihan sebelumnya, dengan harapan bisa meningkatkan keterampilan yang mendukung terhadap peningkatan kualitas perekonomian masyarakat. Sama seperti pelatihan tahap satu, antusiasme masyarakat yang hadir sangat jelas terlihat.

Studi Banding Pengembangan Industri Kreatif Rumahan.

Studi Banding pengembangan industri kreatif rumahan dilaksanakan dengan mengunjungi home industry pengolahan batik. Ini merupakan pelatihan tahap tiga, dan merupakan pelatihan bersama yang telah disinergikan agar bisa menghasilkan masyarakat yang mandiri, kreatif, dan selalu meningkatkan taraf kehidupan perekonomian. Pelatihan ini dihadiri oleh $100 \%$, dari 28 orang yang hadir dalam pelatihan tahap satu. Pelatihan ini memang ditujukan untuk peserta yang telah menghadiri pelatihan sebelumnya, dengan harapan pertama bisa melihat secara langsung yang dalam hal ini batik merupakan pilihan utama dari peserta pelatihan. Kedua meningkatkan keterampilan yang mendukung terhadap peningkatan kualitas perekonomian masyarakat.

Gambar 2

Dokumentasi Pelaksanaan

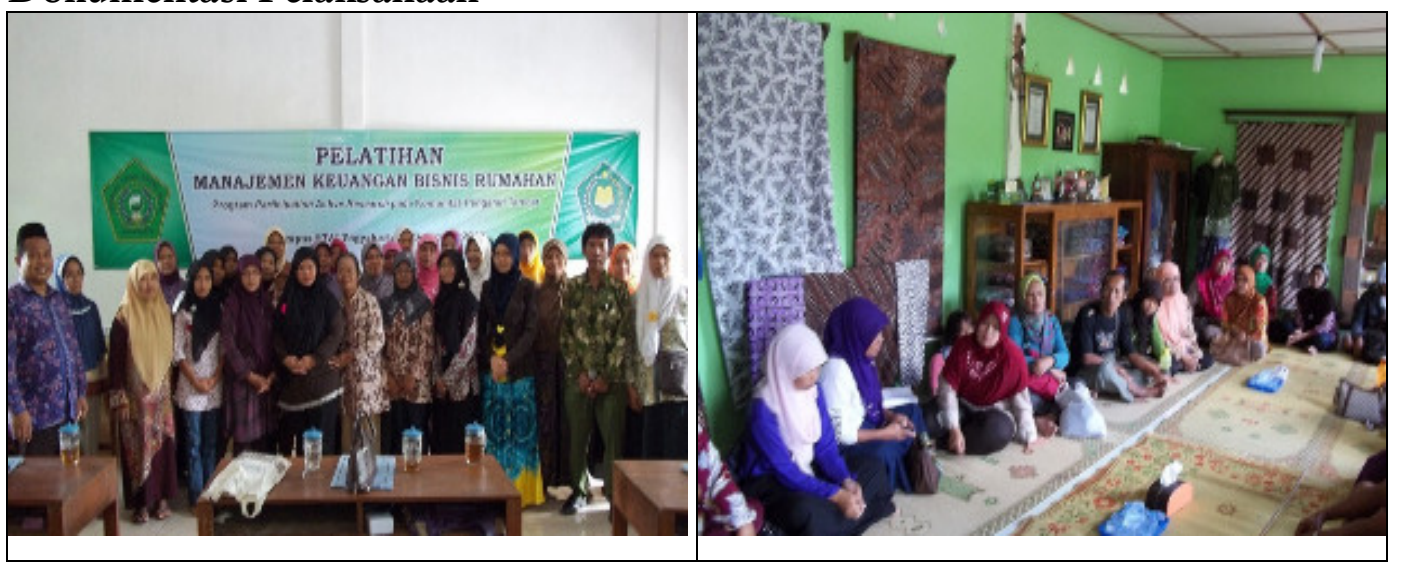





Pembahasan

hambatan yang dialami dan berpotensi mengganggu peningkatan kualitas ekonomi masyarakat diantaranya adalah; 1) Posisi rumah masyarakat yang terpisah-pisah, sehingga menyulitkan masyarakat untuk melakukan kegiatan perekonomian. 2) Manajemen keuangan masih dinilai hal yang baru. Sehingga perlu terus dibina agar terbiasa, dan dipraktekkan dalam aktivitas sehari-hari, terutama pada saat kegiatan berekonomi. 3) Sulit menemukan outlet yang menjual produk hasil kerajinan tangan masyarakat sekitar. Sehingga produk yang bersifat local wisdom tidak terkomunikasikan secara baik kepada masyarakat umum. Sehingga, potensi-potensi lokal, juga tidak bisa tangkap oleh masyarakat umum, khususnya yang berada diluar area Wonosari.

Kearifal lokal atau local wisdom dapat dipahami sebagai gagasangagasan, nilai-nilai-nilai, pandangan-pandangan setempat (local) yang bersifat bijaksana, penuh kearifan, bernilai baik, yang tertanam dan diikuti oleh anggota masyarakatnya. Setiap daerah, memiliki kearifan lokal masingmasing, yang tentu berbeda dengan kearifan lokal daerah lainnya. Karenanya, mengembangkan kearifan lokal yang telah ada, kemudian diarahkan agar bisa menghasilkan nilai lain yang bersifat Economic value, merupakan cara yang positif serta potensial menghasilkan nilai yang tinggi. Hal itu dikarenakan, keunikan yang dimiliki oleh masing-masing daerah. Optimalisasi dilakukan dengan cara sistematisasi alur perekonomian yang sebelumnya cenderung bersifat tradisional, menjadi perekonomian yang bersifat modern. Upaya sistematisasi tersebut, diwujudkan melalui pelatihan manajemen keuangan 
Umi Musaropah, Suharto, Daluti Delimanugari, Agus Suprianto, Rubini,

Retno Kurnianingsih, Citra Ayudiati

bisnis rumahan, kemudian diperkuat dengan pelatihan pengembangan industri kreatif rumahan.

Selain itu, optimalisasi juga dilakukan dengan cara bekerja sama dengan pihak-pihak yang telah lebih dahulu melaksanakan pembinaan masyarakat, seperti pelatihan kain percak, kemudian pelatihan batik tulis sebagaimana yang telah dipaparkan sebelumnya. Adapun capaian perubahan sosial ekonomi yang berhasil diidentifikasi diantaranya adalah kemampuan manajemen keuangan bisnis rumahan yang telah dimiliki oleh peserta. Hal ini bisa diidentifikasi secara cepat dikarenakan kemampuan tersebut, bisa diukur dengan serangkaian test yang dilakukan setelah pelatihan selesai. Selain itu, para peserta juga terlihat sangat antusias ketika mengikuti sesi pelatihan.

Walaupun pada saat pelatihan sesi kedua terjadi hujan yang sangat besar, para peserta tetap hadir di tempat pelatihan. Hal ini menandakan bahwa mereka semua memiliki keinginan yang kuat untuk mengikuti pelatihan ini, dengan kata lain, mereka memiliki keinginan yang kuat untuk merubah tarap perekonomian mereka. Selain itu, di pelatihan tahap dua, para peserta juga bisa langsung mengeluarkan ide-ide kreatif, khususnya dalam rangka inovasi produk yang mereka miliki. Sehingga bisa terus berkreasi, dan menciptakan peluang-peluang usaha baru.

\section{Penutup}

Pengembangan kewirausahaan bagi jamaah wanita MT di desa Kepek Gunung Kidul, bisa tercapai secara baik. Diantaranya adalah; Perlu ada tindak lanjut dalam rangkan pendampingan serta upgrading keterampilan, baik yang bersifat utama maupun pendukung, agar bisa terus meningkatkan kualitas perekonomian masyarakat, khususnya pada majelis taklim di Wonosari. Perlu ada pengembangan jaringan pemasaran secara masif, mengingat potensi kearifan lokal yang baik, agar bisa dikonversi dalam bentuk nilai ekonomi. Pembentukan outlet-outlet khusus yang memasarkan hasil kerajinan tangan masyarakat, sehingga kegiatan perekonomian bisa terus berproses dan memberikan manfaat positif bagi masyarakat sekitar. Dukungan dari pemerintah, untuk mengangkat kearifan lokal yang ada, menjadi salah satu materi sosialisasi daerah dan muatan lokal dalam 
Pengembangan Kewirausahaan Berbasis Industri Kreatif Bagi Jamaah Wanita Majelis Taklim Di Desa Kepek

pendidikan kewirausahaan yang dijalankan dalam pendidikan formal. Sehingga mampu memberikan dampak positif secara langsung, terhadap masyarakatnya.

\section{Daftar Pustaka}

Asmoro, Prabekti. 2009. Hidup-Mati Home Industri di Indonesia pada Era Krisis. Bandung: Penerbit Baru.

Bisri, Hasan, dan Cucu Setiawan. 2019. "Pemberdayaan Ibu-Ibu Jamaah Majelis Talim Melalui Pelatihan Kewirausahaan Syariah Di Desa Balokang Kota Banjar Propinsi Jawa Barat." Al-Khidmat 2(1):40-45. doi: 10.15575/jak.v2i1.5362.

Burhanuddin. 2002. Ulama Perempuan Indonesia. Jakarta: Gramedia Pustaka Utama.

Daulay, Raihanah. 2014. "Strategi Jaringan Usaha Untuk Meningkatkan Pendapatan Masyarakat." Ekonomikawan: Jurnal Ilmu Ekonomi dan Studi Pembangunan 11(12):1-12. doi: 10.30596/EKONOMIKAWAN.V11I12.94.

Fauroni, Lukman, Munawar Ahmad, dan Awan Kostradiharto. 2016. PTKI Entrepreneur Gagasan dan Praktik. diedit oleh E. B. Wiranto. Yogyakarta: Kurnia Kalam Semesta.

Fauroni, R. Lukman, dan Mujahid Quraisy. 2019. "Pesantren Agility in Community Economic Development." Muqtasid: Jurnal Ekonomi dan Perbankan Syariah 10(2):155-68. doi: 10.18326/muqtasid.v10i2.155-168.

Gaffney, Michael. 2008. "Participatory Action Research: An Overview--What Makes It Tick?" Kairaranga 9(1986):9-15.

Helmawati, Helmawati. 2018. "Meningkatkan Pendidikan Perempuan Indonesia melalui Optimalisasi Majelis Ta'lim." INSANCITA 3(1):65-88. doi: 10.2121/INCITA-JISISEA.V3I1.968.

Hermawan, Toto. 2016. "Pengaruh Kemampuan Bertanya Terhadap Hasil Belajar." Intersections 1(1).

Hindarti, Sri, MN Sudjoni, dan Nikmatul Khoiriyah. 2018. "Pemberdayaan majelis talim melalui pengembangan industri rumah tangga bawang merah goreng." Hal. 185-94 in Proceeding Seminar Nasional Peningkatan Kapabilitas UMKM dalam Mewujudkan UMKM Naik Kelas.

Huda, Moh Shofiyul. 2016. "Kontrak Kerja Sama Usaha Di Indonesia Dalam Perspektif Hukum Islam." Realita: Jurnal Penelitian dan Kebudayaan Islam 14(2):135-47. doi: 10.30762/REALITA.V14I2.240.

Huda, Nurul, ed. 1986. Pedoman Majelis Taílim. Jakarta: KODI.

Jacobs, Steven Darryl. 2016. "The Use of Participatory Action Research within Education-Benefits to Stakeholders." World Journal of Education 6(3):48-55. doi: 10.5430/wje.v6n3p48.

Nadjib H., Ahmad, Muh. Jamaluddin, Hilman Haroen, Taufik Nugroho, dan Paiman Paiman. 2019. "Penanaman Nilai-Nilai Kemasyarakatan Di Pesantren Modern." Nuansa Akademik Jumal Pembangunan Masyarakat 4(1):17-32.

Nadjih, Difla, dan F. Setiawan Santoso. 2015. "Sosialisasi Fikih Lingkungan Usulan Pemberdayaan Majelis Taklim Di Desa Nelayan." Ulumuddin: 
Umi Musaropah, Suharto, Daluti Delimanugari, Agus Suprianto, Rubini,

Retno Kurnianingsih, Citra Ayudiati

Jurnal Ilmu-ilmu Keislaman 5(2):65-73.

Prihantoro, Agung, dan Fattah Hidayat. 2019. "Melakukan Penelitian Tindakan Kelas." Ulumuddin: Jurnal Ilmu-ilmu Keislaman 9(1):49-60.

Rahayu, Supriati H., Hidayatul Huda, Joko Wahono, Difla Nadjih, dan A. Zain Sarnoto. 2019. "Implementasi Pendidikan Quran Tingkat Lanjut Bagi Santri Usia Dewasa." Nuansa Akademik Jurnal Pembangunan Masyarakat 4(1):63-78.

Rosha, Zeshasina, Linda Wati, Ice Kamela, Arfan Ananda, dan Fisti Dea M. 2019. "Pemberdayaan Anggota Majelis Talim Al-Ikhlas Melalui Kegiatan Keterampilam Merajut Di Dadok Tunggul Hitam Padang." JMM (Jurnal Masyarakat Mandiri) 2(1):77-82. doi: 10.31764/jmm.v2i1.1351.

Rosmawati, Andi Abdul Azis Ishak, dan Mansur Nurhilaliah. 2017. "Pelatihan Motivasi Dan Kewirausahaan Bagi Ibu-Ibu Majelis Taklim." Hal. 51-56 in Prosiding Seminar Hasil Pengabdian Kepada Masyarakat (SNP2M). Makassar: Politeknik Negeri Ujung Pandang.

Sagala, Rumadani. 2019. "Peran Majelis Taklim Al-Hidayah dalam Pendidikan Islam dan Gerakan Sosial Keagamaan di Propinsi Lampung." Jurnal Studi Kependidikan dan Keislaman 6(1):27-36. doi: 10.1080/01416200.2015.1128390.

Santoso, Fattah Setiawan, Diflah Nadjih, dan Imam Samroni. 2015. Penguatan Budaya Ramah Lingkungan Berbasis Fikih Di Kampung Nelayan Wilayah Poncosari Srandakan Bantul-DIY, Laporan Akademik Program Bantuan Peningkatan Mutu Pengabdian Kepada Masyarakat. Jakarta.

Sarumaha, Yenny Anggreini. 2016. "Perubahan Pembelajaran Yang Berpusat Pada Guru Ke Berpusat Pada Siswa." Intersections 1(1).

Susiana, Eri Widyastuti, dan Ika Purnama Sari. 2017. "Pelatihan Dan Pendampingan Keterampilan Merajut Dan Manajemen Usaha Di Desa Telaga Sari - Deli Serdang." Seminar Nasional Pengabdian Masyarakat Lpm Unimed 2017 (September):177-83.

Sutrisno, Sutrisno. 2018. "Pemberdayaan Anggota Majelis Taklim Melalui Usaha Susu Kedelai Dan Nugget." Comvice: Journal of community service 2(2):21-28. doi: 10.26533/comvice.v2i2.167.

Winn, Phillip. 2012. "Women's majelis taklim and gendered religious practice in northern Ambon." Intersections: Gender and Sexuality in Asia and the Pacific (30).

Zainuri, M. Sulkhan, Hartoyo, Muhajir, MNK Al Amin, Andri Irawan, dan Iin Sunny Atmadja. 2019. "Analisis Penyebab Pernikahan Usia Dini Di Kecamatan Pleret Kabupaten Bantul." Nuansa Akademik Jurnal Pembangunan Masyarakat 4(1):33-46. 